\title{
PENGARUH KEPEMILIKAN KELUARGA DAN KEPEMILIKAN INSTITUSIONAL TERHADAP NILAI PERUSAHAAN
}

\author{
Dina Patrisia, Halkadri Fitra,Luli Febrianti \\ Universitas Negeri Padang, Padang \\ patrisiadina@yahoo.com
}

\begin{abstract}
ABSTRAK:
Pengaruh kepemilikan keluarga dan kepemilikan institusional terhadap nilai perusahaan. Tujuan penelitian ini adalah menyelidiki pengaruh kepemilikan keluarga dan kepemilikan Institusional terhadap nilai perusahaan. Populasi pada penelitian terdiri atas seluruh perusahaan manufaktur yang terdaftar pada Bursa Efek Indonesia pada periode 20122016. Pengambilan sampel didasarkan pada purposive sampling dengan kriteria kelengkapan data, sehingga total sampel terdiri atas 559 pengamatan. Data yang digunakan adalah secondary data. Analisis data menggunakan metode Multiple regression. Hasil analisis data memperlihatkan bahwa kepemilikan keluarga dengan pengukuran dummy keterlibatan dalam jajaran direksi atau komisaris memiliki pengaruh negative terhadap nilai perusahaan. Sementara kepemilikan Institusional memiliki tidak memiliki pengaruh terhadap nilai perusahaan manufaktur yang terdaftar di Bursa Efek Indonesia
\end{abstract}

Keywords: firm value, family ownership, institutional ownership

\begin{abstract}
:
Pengaruh kepemilikan keluarga dan kepemilikan institusional terhadap nilai perusahaan. This study aims to analyze the effect of family ownership and institutional ownership on firm value. The population in this study are all Manufacturing companies listed on the Stock Exchange in 2012-2016. The sampling technique used purposive sampling technique with a total of 559 samples. The data used is secondary data. The data analysis method used is multiple regression. The results of the study concluded that family ownership variables proxied by family member dummy had a negative and significant effect on firm value but family ownership dummy and family ownership percentage had a negative and insignificant effect on firm value. Institutional ownership has a negative and insignificant effect on the value of the company in manufacturing companies listed on the IDX.
\end{abstract}

Keywords: firm value, family ownership, institutional ownership 


\section{PENDAHULUAN}

Dalam jangka panjang tujuan perusahaan ialah memaksimumkan nilai perusahaan. Nilai perusahaan yang tinggi dapat mencerminkan kemakmuran para pemegang saham dan nilai perusahaaan terutama perusahaan publik akan tercermin pada harga sahamnya (Haruman, 2008; Pujiati \& Widanar, 2009).

Dalam proses memaksimalkan nilai perusahaan akan muncul konflik kepentingan antara manajer dan pemegang saham (pemilik perusahaan) yang disebut dengan permasalahan keagenan. Tidak jarang pihak manajemen yaitu manajer perusahaan mempunyai tujuan dan kepentingan lain yang bertentangan dengan tujuan utama perusahaan dan sering mengabaikan kepentingan pemegang saham. Nam, Tang, Thornton, and Wynne (2006) mengatakan bahwa perusahaan yang memiliki agency conflict yang kecil cenderung mempunyai nilai perusahaan yang relatif tinggi. Terlebih lagi hasil empiris menemukan bahwa masalah agensi sangat mempengaruhi keputusan dan kebijakan perusahaan dalam meningktakan nilai perusahaan (Harahap \& Wardhani, 2012)

Menurut hasil Family Survey Business (PWC, 2014) sekitar 95\% perusahaan di Indonesia adalah dimiliki oleh keluarga, dan sebaran sektor kepemilikan perusahaan oleh keluarga yang paling mendominasi ialah pada sektor manufaktur dibandingkan sektor-sektor lainnya.

Kepemilikan saham oleh keluarga pendiri memiliki kecenderungan untuk melakukan monitoring yang bisa memperkecil masalah keagenan karena pemilik dan manajemen perusahaan merupakan pihak yang sama dan tidak akan terjadi perbedaan kepentingan. Biasanya sebagian besar harta keluarga diinvestasikan kedalam perusahaan tersebut dan tidak terdiversifikasi dengan baik, sehingga mereka begitu peduli terhadap kelangsungan perusahaan dan memiliki dorongan kuat untuk melakukan pengawasan (Pukthuanthong, 2013). Walaupun demikian, beberapa penelitian menemukan bahwa perusahaan yang dikendalikan keluarga terkadang melakukan upaya untuk melestarikan kekayaan social-emosional keluarga walaupun mengorbankan kinerja keuangan perusahaan (Rouyer, 2016).

Begitu pula dengan Investor institusional dianggap sebagai pihak yang efektif dalam melakukan pengawasan setiap tindakan yang dilakukan oleh manajer. Investor institusional diharapkan mengambil bagian dalam setiap aktivitas internal perusahaan sehingga mampu mengawasi setiap tindakan oportunistik manajer (Jensen \& Meckling, 1976; Lin \& Fu, 2017; Pillai \& Al-Malkawi, 2018; Sari \& Patrisia, 2019)

Penelitian ini menggunakan nilai perusahaan sebagai variabel dependen yang diproksikan dengan Tobin's Q. Sedangkan kepemilikan keluarga dan kepemilikan institusional sebagai variabel independen. Variabel independen dipilih karena berdasarkan hasil penelitian terdahulu menyatakan hasil penelitian tidak konsisten mempengaruhi nilai perusahaan. Penelitian yang dilakukan Altindag, Zehir, and Acar (2011); Amran and Ahmad (2010); Andres (2011); Barontini and Caprio (2006); Chu (2011); Lee (2006); Martínez and Requejo (2017); Villalonga and Amit (2006) menemukan bahwa adanya pengaruh positif antara kepemilikan keluarga dengan nilai perusahaan. Sedangkan Abdullah, Shah, Gohar, and lqbal (2011); Connelly, Limpaphayom, and Nagarajan (2012); Miller, Le Breton-Miller, Lester, and Cannella (2007) menemukan bahwa kepemilikan keluarga berpengaruh negatif terhadap nilai perusahaan. Sementara Rouyer (2016) tidak menemukan pengaruh kepemilikan keluarga terhadap kinerja perusahaan.

Hasil penelitian tentang kepemilikan institusional terhadap nilai perusahaan yang dilakukan Lin and Fu (2017); Melinda and Sutedo (2008); Widianingsih (2018) menyatakan bahwa kepemilikan institusional berpengaruh positif terhadap nilai perusahaan, sedangkan penelitian yang dilakukan Isshaq (2009); Sari and Patrisia 
(2019) menemukan bahwa kepemilikan institusional tidak berpengaruh terhadap nilai perusahaan.

Berdasarkan uraian diatas masih terdapatnya ketidak konsistenan hasil penelitian terdahulu mengenai pengaruh kepemilikan keluarga dan kepemilikan institusional terhadap nilai perusahaan maka peneliti tertarik untuk meneliti lebih lanjut dengan sampel dan periode yang berbeda dengan penelitian terdahulu.

\section{KAJIAN LITERATUR}

Teori yang digunakan untuk menyatakan hubungan antar variabel dalam penelitian ini, maka digunakan dua grand theory yaitu teori Hubungan Keagenan (Agency Theory) dan Tata Kelola Perusahaan Corporate Governance (CG). Dalam perspektif Tata Kelola perusahaan, Agency theory digunakan sebagai dasar untuk mengembang Tata Kelola perusahaaan yang baik (Pillai \& Al-Malkawi, 2018). Hubungan keagenan yang merupakan salah satu bentuk interaksi sosial yang paling tua dan sering muncul ketika ada pemisahan fungsi pengelolaan dan fungsi kepemilikan, dimana salah satu pihak (agent) bertindak sebagai perwakilan pihak lain (principal) dalam pengambilan keputusan (Liviani, Mahadwartha, \& Wijaya, 2016).

Menurut Jensen and Meckling (1976) Teori keagenan ialah teori yang menjelaskan mengenai sebuah fenomena ketidaksamaan kepentingan antara principal dengan agent. Hubungan keagenan adalah sebuah kontrak antara pihak pemegang saham (principal) dengan pihak manajer perusahaan (agent). Inti dari hubungan keagenan ini ialah adanya pemisahan antara kepemilikan perusahaan dengan pengendalian perusahaan. Adanya perbedaan kepentingan antara kedua belah pihak dapat menimbulkan masalah keagenan.

Permasalah keagenan muncul saat kepengurusan suatu perusahaan terpisah dari kepemilikannya. Corporate governance ialah semua upaya untuk mencari cara terbaik dalam menjalankan suatu perusahaan, dimana kebijakan-kebijakan dan peraturan yang ada dalam corporate governance dapat digunakan untuk mengontrol manajemen (Harahap \& Wardhani, 2012)

Menurut International Finance Corporation (2014, p. 30) corporate governance adalah struktur dan proses untuk mengarahkan dan mengawasi jalannya perusahaan. Lebih lanjut, Hitt, Ireland, and Hoskisson (2011, p. 286) mendefenisikan bahwa Corporate governance adalah mekanisme yang digunakan untuk menjaga hubungan antara stakeholders dan untuk menentukan serta mengontrol arah keputusan strategic dan pencapaian kinerja organisasi. Seiring dengan itu Forum for Corporate Governance in Indonesia (FCGI, 2001) menyatakan bahwa corporate governance merupakan seperangkat peraturan yang menetapkan hubungan antara pemegang saham, manajemen, pihak kreditur, pemerintah, karyawan, serta pemegang kepentingan internal dan eksternal lainnya sehubungan dengan hak-hak dan kewajiban mereka, atau dengan kata lain corporate governance adalah sistem yang mengarahkan dan mengendalikan perusahaan. Dengan melakukan pengawasan yang diarahkan pada perilaku manajer agar bisa dinilai apakah tindakannya bermanfaat bagi perusahaan (pemilik) atau bagi manajer itu sendiri. Secara umum penerapan dari good corporate governance dipercaya mampu meningkatkan kinerja atau nilai perusahaan

Menurut Pukthuanthong (2013) kepemilikan keluarga dalam suatu perusahaan dampak memberikan dampak positif ataupun negatif terhadap nilai perusahaan. Pemilikan saham yang cukup besar membuat keluarga memiliki peran yang besar dalam mengawasi keputusan manajemen sehingga sejalan dengan peningkatan nilai perusahaah. Sebaliknya kepemilikan keluarga yang besar dan keterlibatan dalam pengelolaan perusaahaan dapat membuat mereka mengambil keputusan yang lebih 
mementingkan nilai non keuangan seperti nilai sosial dalam keluarga dibandingkan dengan kepentingan kinerja keuangan perusahaaan.

Komalasari and Nor (2014) menyatakan kepemilikan keluarga dapat meminimalkan atau menghilangkan biaya keagenan dikarenakan pemilik dan manajemen perusahaan merupakan pihak yang sama. Kepemilikan perusahaan oleh keluarga, biasanya terlihat dari adanya anggota keluarga yang memiliki jabatan di jajaran pada manajemen puncak perusahaan. Selain itu, dalam perusahaan yang dimiliki oleh keluarga biasanya terjadi transfer pengalaman dan pengetahuan dari geneasi satu ke generasi berikutnya. Jika generasi penerus tumbuh dan sudah lama berada dalam perusahaan akan menciptakan hubungan yang penuh rasa kepercayaan dengan karyawan dan hubungan yang berorientasi jangka panjang dengan pemasok dan pihak luar lainnya

Perusahaan keluarga dapat menciptakan kepercayaan dan loyalitas pekerjaan sehingga akan menurunkan biaya rekrutmen dan pergantian karyawan dalam perusahaan Andres (2011). Pertimbangan dalam berinvestasi pada perusahaan keluarga cenderung lebih berhati-hati dibandingkan dengan perusahaan non-keluarga. Perusahaan non-keluarga cenderung melakukan pertimbangan jangka pendek dengan melihat fluktuasi harga saham. Berbeda dengan perusahaan keluarga yang mempertimbangkan kelangsungan perusahaan jangka panjang sehingga menghasilkan keputusan investasi yang lebih baik (Shyu, 2011).

Penelitian yang dilakukan Amran and Ahmad (2010); Barontini and Caprio (2006); Villalonga and Amit (2006) menemukan bahwa ketika sebuah perusahaan dengan kepemelikan keluarga dikelola oleh anggota keluarga, maka konflik antara pemegang saham dan manajer dapat diminimalkan, sehingga hal ini dapat menghilangkan biaya keagenan dan mampu meningkatkan nilai perusahaa. Sedangkan Abdullah et al. (2011); Connelly et al. (2012); Miller et al. (2007) menemukan bahwa kepemilikan keluarga berpengaruh negatif terhadap nilai perusahaan. Hal ini dikarenakan kepemilikan keluarga lebih tertuju pada keuntungan pribadi sehingga berdampak buruk pada profitabilitas dan nilai perusahaan.

Hasil penelitian tentang kepemilikan institusional terhadap nilai perusahaan yang dilakukan Lin and Fu (2017); Melinda and Sutedo (2008); Widianingsih (2018) menyatakan bahwa kepemilikan institusional berpengaruh positif terhadap nilai perusahaan. Hal ini dikarenakan kepemilikan institusional yang cukup besar dalam suatu perusahaan akan mendorong meningkatkan pengawasan dalam setiap aktivitas internal perusahaan sehingga mampu mengawasi tindakan oportunistik manajer. Sedangkan penelitian yang dilakukan Isshaq (2009); Sari and Patrisia (2019) kepemilikan institusional tidak berpengaruh terhadap nilai perusahaan. Hal ini disebabkan karena masih rendahnya tingkat kepemilikan institusional, sehingga perusahaan tidak memiliki sumber daya yang cukup untuk dapat melakukan kontrol dengan baik semua tindakan manajer. Berdasarkan penjelasan ini dapat dikembangkan hipotesis sebagai berikut:

$\mathrm{H} 1$ : Kepemilikan Keluarga berpengaruh terhadap nilai perusahaan

$\mathrm{H} 2$ : Kepemilikan Institusi berpengaruh positif terhadap nilai perusahaan

\section{METODE}

Pada metodologi penelitian ini akan dijelaskan mengenai jenis penelitian, objek, data dan sumber data serta teknik pengambilan sampel dan definisi operasionalnya. Penelitian ini tergolong penelitian kausatif dengan objek penelitian adalah seluruh Perusahaan Manufaktur yang terdaftar di BEI. Terdapat 142 perusahaan manufaktur yang tercatat selama periode penelitian, yaitu tahun 2012-2016. Beberapa perusahaan tidak terdaftar berturut turut dan tidak menerbitkan laporan keuangan yang lengkap sehingga hanya 119 perusahaan dari 142 perusahaan yang menjadi sampel penelitian. 
Dengan demikian sampel penelitian ini adalah sebanyak 119 perusahaan selama lima tahun pengamatan, maka didapatkan sampel sebanyak 599 sampel. Semua data bersumber dari laporan tahunan perusahaan yang diterbitkan oleh Bursa Efek Indonesia.

Variabel- variabel pada penelitian ini dikelompokkan menjadi tiga. Pertama adalah variabel dependent berupa nilai perusahaan. Kedua adalah variabel independent yang terdiri atas kepemilikan institusional dan kepemilikan keluarga. Kepemilikan keluarga dibedakan atas persentase kepemilikan saham oleh keluarga, dummy perusahaan dengan kepemilikan keluarga atau bukan, dummy perusahaan keluarga dengan anggota keluarga yang terlibat dalam jajaran direksi dan komisaris. Ketiga adalah variabel kontrol yang terdiri atas kebijakan dividen, kebijakan utang dan ukuran perusahaan (firm size). Defenisi dan pengukuran variabel-variabel ini dapat dilihat pada Tabel 1. 
Tabel 1 Definisi Operasional Variabel

\begin{tabular}{|c|c|c|c|}
\hline & Definisi Operasional & Proksi & Sumber \\
\hline \multicolumn{4}{|c|}{ Variabel Dependen } \\
\hline $\begin{array}{l}\text { Nilai } \\
\text { Perusahaan }\end{array}$ & $\begin{array}{l}\text { Rasio pasar terhadap } \\
\text { nilai buku yang dihitung } \\
\text { dengan rasio harga } \\
\text { pasar ekuitas ditambah } \\
\text { hutang dibagi dengan } \\
\text { nilai aset perusahaan }\end{array}$ & $\begin{array}{l}\text { Tobin's } q \\
=\frac{\text { market value of equity }+ \text { totaldebt }}{\text { total asset }}\end{array}$ & $\begin{array}{l}\text { Adnantara } \\
\text { (2014); Benson } \\
\text { and Davidson } \\
\text { (2009) }\end{array}$ \\
\hline \multicolumn{4}{|c|}{ Variabel Independen } \\
\hline $\begin{array}{l}\text { Kepemilikan } \\
\text { Institusional }\end{array}$ & $\begin{array}{l}\text { Persentase kepemilikan } \\
\text { saham oleh sebuah } \\
\text { institusi atau lembaga } \\
\text { tertentu dibandingkan } \\
\text { dengan jumlah saham } \\
\text { yang beredar. }\end{array}$ & $I N S T=\frac{\sum \text { Saham institusi }}{\sum \text { saham beredar }} \times 100$ & $\begin{array}{l}\text { Adnantara } \\
\text { (2014); Lin and } \\
\text { Fu (2017) }\end{array}$ \\
\hline $\begin{array}{l}\text { Kepemilikan } \\
\text { Keluarga }\end{array}$ & $\begin{array}{l}\text { Perusahaan yang } \\
\text { kepemilikan sahamnya } \\
\text { terkonsentrasi terhadap } \\
\text { sebuah keluarga } \\
\text { tertentu serta } \\
\text { menempatkan anggota } \\
\text { keluarganya di jajaran } \\
\text { komisaris atau posisi } \\
\text { dalam manajemen } \\
\text { lainnya. }\end{array}$ & $\begin{array}{l}\text { 1. Familiy OwnershipDummy } \\
\text { 2. family ownership percentage } \\
\quad \frac{\sum \text { saham keluarga }}{\sum \text { saham beredar }} \times 100 \\
\text { 3. Family Board or CEO } \\
\text { member Dummy }\end{array}$ & $\begin{array}{l}\text { Pukthuanthong } \\
\text { (2013); Rouyer } \\
\text { (2016); } \\
\text { Villalonga and } \\
\text { Amit (2006) }\end{array}$ \\
\hline \multicolumn{4}{|c|}{ Variabel Kontrol } \\
\hline $\begin{array}{l}\text { Kebijakan } \\
\text { Dividen }\end{array}$ & $\begin{array}{l}\text { Kebijakan pembagian } \\
\text { laba yang diperoleh } \\
\text { perusahaan akan } \\
\text { dibagikan kepada } \\
\text { pemegang saham yang } \\
\text { terlihat pada divident } \\
\text { payout ratio. }\end{array}$ & $D P R=\frac{\text { Dividen per share }}{\text { Earning per share }}$ & $\begin{array}{l}\text { Villalonga and } \\
\text { Amit (2006) }\end{array}$ \\
\hline $\begin{array}{l}\text { Kebijakan } \\
\text { Hutang }\end{array}$ & $\begin{array}{l}\text { Tindakan manajemen } \\
\text { perusahaan dalam } \\
\text { mendanai kegiatan } \\
\text { operasional perusahaan } \\
\text { yang diperlihatkan dari } \\
\text { hasil total hutang dibagi } \\
\text { dengan total ekuitas. }\end{array}$ & Lev $=\frac{\text { Total hutang }}{\text { Total ekuitas }}$ & $\begin{array}{l}\text { Martínez and } \\
\text { Requejo (2017); } \\
\text { Pillai and Al- } \\
\text { Malkawi (2018) }\end{array}$ \\
\hline Firm size & $\begin{array}{l}\text { Ukuran perusahaan } \\
\text { menunjukkan besar } \\
\text { kecilnya perusahaan } \\
\text { yang dapat dilihat dari } \\
\text { total aktiva yang dimiliki. }\end{array}$ & Ln aset & Rouyer (2016) \\
\hline
\end{tabular}

Sumber: Berbagai Artikel 
Penelitian ini menggunakan analisis regresi berganda sebagai alat analisis. Dikarenakan kemungkinan timbulnya korelasi antar pengukuran kepemilikan manajerial, maka penelitian ini menggunakn tiga model regresi. Berikut ini adalah model yang dibangun dalam penelitian ini :

$$
\begin{gathered}
\text { Tobin } Q=a+b_{1} \text { FO Dummy }+b_{2} \text { INST }+b_{3} \text { DPR }+b_{4} \text { DER }+b_{5} \text { Ln aset }+e \\
\text { Tobin } Q=a+b_{1} \text { FO Percentage }+b_{2} \text { INST }+b_{3} \text { DPR }+b_{4} \text { DER }+b_{5} \text { Ln aset }+e \\
\text { Tobin } Q=a+b_{1} \text { FO Board or CEO member Dummy }+b_{2} I N S T+b_{3} \text { DPR }+ \\
\quad b_{4} \text { DER }+b_{5} \text { Ln aset }+e
\end{gathered}
$$

Sebelum melakukan analisis regresi, terlebih dahulu dilakukan pengujian asumsi klasik yang meliputi uji Outlier menggunakan metode z-score, Uji Normalitas dengan metode Kolmogorof-Smirnov Test, Uji Multikolinearitas, Uji Autokorelasi menggunakan metode Runs Test, dan Uji Heterokedastisitas dengan metode Koefisien Korelasi Spearmen. Hasil pengujian regresi berganda pada ketiga model dinyatakan telah lulus uji dengan metode yang telah disebutkan.

\section{HASIL DAN PEMBAHASAN}

\section{Statistik Deskriptif}

Berdasarkan output statistik pada Tabel 2 dapat dilihat bagaimana gambaran tentang variabel-variabel penelitian yang akan dianalisis dalam penelitian ini. Statistik deskriptif terdiri dari nilai maksimum, minimum, rerata hingga standar deviasi. Untk lebih jelasnya, berikut ini penjelasan masing-masing variabel :

Tabel 2 Deskripsi Statistik Variabel Penelitian

\begin{tabular}{llrrrr}
\hline & N & Minimum & Maximum & Mean & $\begin{array}{r}\text { Std. } \\
\text { Deviation }\end{array}$ \\
\hline Nilai Perusahaan (Tobin's Q) & 599 & 0,30 & 27,04 & 1,84 & 2,48 \\
Family Ownership dummy & 599 & 0,00 & 1,00 & 0,37 & 0,48 \\
Family Ownership Percentage & 599 & 0,00 & 95,38 & 20,82 & 28,95 \\
Family member dummy & 599 & 0,00 & 1,00 & 0,36 & 0,48 \\
Kepemilikan Institusional & 599 & 0,00 & 92,42 & 16,41 & 25,94 \\
Ln aset & 599 & 6,85 & 19,75 & 14,47 & 1,64 \\
Debt to Equity Ratio & 599 & $-8,59$ & 14,72 & 1,20 & 2,07 \\
Dividend Payout Ratio & 599 & $-60,47$ & 100,00 & 10,30 & 20,38 \\
Valid N (listwise) & 599 & & & & \\
\hline
\end{tabular}

Sumber: Hasil Olah SPSS

Berdasarkan output statistik deskriptif pada Tabel 2 terlihat bahwa jumlah sampel yang digunakan dalam penelitian ini adalah 599 observasi. Perusahaan manufaktur dari tahun 2012-2016 memiliki rata-rata Tobin's Q sebesar 1,84. Selanjutnya Variabel independen kepemilikan keluarga yang diproksikan dengan : 1)Family ownership dummy diperoleh rata-rata 0,37, 2)Family Ownership Percentage diperoleh rata-rata 21,08 3)Family member Dummy dengan rata-rata nilai ialah 3,68. Variabel independen kedua pada penelitian ini ialah kepemilikan institusional, diperoleh rata-rata sebesar 16,41 .

Selanjutnya variabel kontrol yang pertama dalam penelitian ini ukuran perusahaan diproksikan dengan menggunakan Ln total aset. Nilai rata-rata dari Ln total aset untuk 599 perusahaan ialah sebesar 14,47, selanjutnya Debt Equity Ratio (DER) terlihat 
bahwa rata-rata keseluruhan perusahaan adala sebesar 1,20 dan yang ketiga kebijakan dividen memiliki nilai rata-rata sebesar 10,21.

\section{Analisis Regresi Linear Berganda}

Dalam penelitian ini model regresi berganda digunakan menyatakan hubungan fungsional antara variabel independen/bebas dan variabel dependen/terikat. Berikut ini adalah hasil olahan data yang diperoleh: 
Tabel 3 Analisis Regresi Linear Berganda

\begin{tabular}{|c|c|c|c|c|c|c|c|c|c|c|c|c|c|c|c|}
\hline & \multicolumn{5}{|l|}{ Model 1} & \multicolumn{5}{|l|}{ Model 2} & \multicolumn{5}{|l|}{ Model 3} \\
\hline & \multicolumn{2}{|c|}{ Unstnd. Coeff } & \multicolumn{3}{|l|}{$\begin{array}{l}\text { Stnd. } \\
\text { Coeff }\end{array}$} & \multicolumn{2}{|c|}{ Unstnd. Coeff } & \multicolumn{3}{|l|}{$\begin{array}{l}\text { Stnd. } \\
\text { Coeff }\end{array}$} & \multicolumn{2}{|c|}{ Unstnd. Coeff } & \multicolumn{3}{|l|}{$\begin{array}{l}\text { Stnd. } \\
\text { Coeff }\end{array}$} \\
\hline & $\bar{B}$ & $\begin{array}{l}\text { Std. } \\
\text { Error }\end{array}$ & Beta & $\bar{T}$ & Sig. & $\bar{B}$ & $\begin{array}{l}\text { Std. } \\
\text { Error }\end{array}$ & Beta & $\bar{T}$ & Sig. & $\bar{B}$ & $\begin{array}{l}\text { Std. } \\
\text { Error }\end{array}$ & Beta & $\bar{t}$ & Sig. \\
\hline (Constant) & 0,056 & 0,940 & & 0,059 & 0,953 & 0,098 & 0,937 & & 0,150 & 0,917 & 0,210 & 0,935 & & 0,221 & 0,823 \\
\hline FO Dummy & $-0,212$ & 0,222 & $-0,39$ & $-0,958$ & 0,338 & & & & & & & & & & \\
\hline FO \% & & & & & & $-0,005$ & 0,004 & $-0,060$ & $-1,474$ & 0,141 & & & & & \\
\hline FM dummy & & & & & & & & & & & $-0,509$ & 0,222 & $-0,092$ & $-2,294$ & 0,022 \\
\hline INST & $-0,003$ & 0,004 & $-0,025$ & $-0,616$ & 0,538 & $-0,003$ & 0,004 & $-0,032$ & $-0,796$ & 0,427 & $-0,004$ & 0,004 & $-0,041$ & $-1,020$ & 0,308 \\
\hline Ln_aset & 0,106 & 0,064 & 0,066 & 1,647 & 0,100 & 0,106 & 0,064 & 0,066 & 1,654 & 0,099 & 0,105 & 0,064 & 0,065 & 1,635 & 0,103 \\
\hline DER & $-0,031$ & 0,050 & $-0,024$ & $-0,620$ & 0,536 & $-0,031$ & 0,049 & $-0,024$ & $-0,620$ & 0,535 & $-0,026$ & 0,049 & $-0,020$ & $-0,526$ & 0,599 \\
\hline DPR & 0,042 & 0,005 & 0,321 & 7,937 & 0,000 & 0,042 & 0,005 & 0,321 & 7,984 & 0,000 & 0,041 & 0,005 & 0,316 & 7,860 & 0,000 \\
\hline$N$ & 599 & & & & & 599 & & & & & 599 & & & & \\
\hline F test & 17,069 & & & & & 17,356 & & & & & 18,062 & & & & \\
\hline Adjusted $\mathrm{R}^{2}$ & 0,118 & & & & & 0,120 & & & & & 0,125 & & & & \\
\hline
\end{tabular}


(online)

Vol 4, No 2, Desember 2019

http://journal.undiknas.ac.id/index.php/manajemen

Dari Tabel 3 tersebut dapat dijelaskan bahwa Nilai koefisien FO dummy pada Model 1 bernilai $-0,212$ dengan nilai t hitung $-0,958$ (sig.0,338>0,05), menunjukkan berpengaruh secara negatif tidak signifikan. Hal ini berarti apabila perusahaan yang memiliki kepemilikan dalam bentuk saham oleh anggota keluarga besar dari 5\%, tidak akan menurunkan secara signifikan nilai perusahaan pada perusahaan manufaktur tahun 2012 sampai 2016. Selanjutnya ialah Nilai koefisien FO percentage pada Model 2 bernilai $-0,005$ dengan nilai t hitung $-1,474$ (sig.0,141>0,05), menunjukkan bahwa persentase kepemilikan perusahaan dalam bentuk saham oleh keluarga berpengaruh secara negatif dan tidak signifikan terhadap nilai perusahaan. Artinya bahwa kepemilikan perusahaan oleh keluarga tidak berpengaruh terhadap nilai perusahaan pada perusahaan manufaktur tahun 2012 sampai 2016. Berdasarkan hasil tersebut maka hipotesis satu pada Model 1 dan 2 tidak terdukung.

Berikutnya pada Model 3 nilai koefisien FM dummy bernilai -0,509 dengan nilai t hitung $-2,294$ (sig.0,022>0,05), menunjukkan bahwa perusahaan yang anggota keluarga menjabat dalam jajaran direksi dan komisaris memiliki rata-rata nilai perusahaan yang lebih rendah dibandingkan dengan rata-rata nilai perusahaan yang tidak terdapat anggota keluarga dalam jajaran direksi atau komisaris pada perusahaan manufaktur tahun 2012 sampai 2016. Berdasarkan hasil tersebut maka Hipotesis satu pada Model 3 terdukung.

Hipotesis kedua dari setiap model penelitian ini ialah kepemilikan institusional (INST). Nilai koefisien INST pada Model 1 dan Model 2 yaitu sebesar $-0,003$ sedangkan model 3 sebesar $-0,004$ dengan nilai t hitung masing-masing model yaitu sebesar -0,616, -0796 dan -1,020 (sig.0,538, 0,427 dan 0,308 > 0,05), menunjukkan bahwa jumlah persentase kepemilikan perusahaan oleh institusi pada Model 1, Model 2 dan Model 3 memiliki pengaruh yang negatif namun tidak signifikan terhadap nilai perusahaan. Artinya bahwa setiap peningkatan persentase kepemilikan oleh institusi tidak akan mempengaruhi nilai perusahaan manufaktur pada tahun 2012 sampai 2016. Berdasarkan hasil tersebut maka hipotesis dua pada setiap model tidak terdukung.

\section{Pembahasan}

Berdasarkan hasil olahan pada model 1 dimana variabel kepemilikan keluarga diproksikan dengan FO dummy menunjukkan bahwa perusahaan yang memiliki kepemilikan dalam bentuk saham oleh anggota keluarga besar dari $5 \%$, tidak akan menurunkan secara signifikan nilai perusahaan. Begitupun dengan nilai koefisien FO percentage pada Model 2 menunjukkan bahwa persentase kepemilikan perusahaan dalam bentuk saham oleh keluarga berpengaruh secara negatif namun tidak signifikan terhadap nilai perusahaan pada perusahaan manufaktur tahun 2012 sampai 2016. Temuan ini relevan dengan penelitian yang dilakukan oleh Rouyer (2016) yang menyatakan bahwa kepemilikan keluarga tidak berpengaruh terhadap nilai perusahaan. Tidak signifikannya kepemilikan keluarga dalam bentuk dummy dan persentase diduga dikarenakan kepemilikan keluarga pada industri manufaktur masih sedikit. Perusahaan keluarga masih berada pada kisaran $37 \%$ sedangkan rata-rata persentase saham kepemilikan keluarga adalah 20,82\% (Lihat Tabel 1)

Akan tetapi berbeda dengan hasil olahan data pada Model 3 menunjukkan variabel kepemilikan keluarga yang diproksikan dengan FM dummy berpengaruh negatif dan signifikan. Berarti bahwa perusahaan yang terdapat anggota keluarga 
(online)

Vol 4, No 2, Desember 2019

http://journal.undiknas.ac.id/index.php/manajemen

menjabat dalam jajaran direksi dan komisaris memiliki rata-rata nilai perusahaan yang lebih rendah dibandingkan dengan rata-rata nilai perusahaan yang tidak terdapat anggota keluarga dalam jajaran direksi atau komisaris pada perusahaan manufaktur tahun 2012 sampai tahun 2016.

Hasil penelitian pada Model 3 relevan dengan penelitian Abdullah et al. (2011); Connelly et al. (2012); Miller et al. (2007) yang menemukan bahwa perusahaan keluarga lebih tertuju pada keuntungan pribadi sehingga berdampak buruk pada profitabilitas dan nilai perusahaan. Hal ini juga bisa terjadi karena adanya benturan antara kepentingan keluarga dan kepentingan perusahaan yang menyebabkan toleransi kepada orang yang tidak kompeten dan menutup kemungkinan masuknya orang yang sebenarnya berpotensi. Perusahaan yang dikendalikan keluarga melalui keterlibatan dalam pengelolaan perusahaan ternyata berdampak dalam melakukan upaya untuk melestarikan kekayaan socialemosional keluarga, walaupun keputusan ini dapat mengorbankan kinerja keuangan perusahaan.

Namun hasil penelitian pada Model 1, Model 2, dan Model 3 memberikan hasil yang berbeda dengan beberapa penelitian sebelumnya seperti penelitian yang dilakukan oleh Altindag et al. (2011); Amran and Ahmad (2010); Andres (2011); Barontini and Caprio (2006); Chu (2011); Lee (2006); Martínez and Requejo (2017); Villalonga and Amit (2006) dalam penelitiannya yang menggunakan beberapa sampel perusahaan di beberapa negara Eropa dan Malaysia menemukan adanya hubungan positif signifikan antara kepemilikan keluarga dan nilai perusahaan.

Dari hasil penelitian pada Model 1, Model 2 dan Model 3 hal ini berarti kepemilikan perusahaan oleh keluarga hanya akan berpengaruh negatif dan signifikan jika ada anggota keluarga yang memiliki peran sebagai direktur atau komisaris sehingga terlibat dalam pengambil keputusan diperusahaan. Sehingga hipotesis pertama hanya terdukung secara parsial, yaitu berdasarkan FMember dummy.

Berdasarkan hasil olahan pada Model 1, Model 2 dan Model 3 variabel kepemilikan institusi menunjukkan bahwa jumlah persentase kepemilikan perusahaan oleh institusi memiliki arah pengaruh yang negatif namun tidak signifikan terhadap nilai perusahaan. Hasil penelitian ini relevan dengan penelitian yang dilakukan Isshaq (2009); Sari and Patrisia (2019) dalam bahwa kepemilikan oleh institusional tidak berpengaruh terhadap nilai perusahaan. Akan tetapi hasil penelitian berbeda dengan penelitian yang dilakukan oleh Lin and Fu (2017); Melinda and Sutedo (2008); Widianingsih (2018) yang menemukan adanya pengaruh yang signifikan antara kepemilikan institusional pada nilai perusahaan yang terdaftar di Bursa Efek Indonesia.

Berdasarkan hasil ini Hipotesis 2 pada Model 1, Model 2 dan Model 3 tidak terdukung. Hasil ini bisa saja disebabkan oleh kepemilikan saham oleh institusi yang relative rendah pada penelitian ini (Lihat Tabel 1). Struktur kepemilikan saham pada perusahaan di Indonesia cenderung terkonsentrasi, sehingga kepemilikan institusional yang bukan pemilik mayoritas tidak mampu memonitor kinerja manajer dengan baik. Tidak terdukungnya hipotesis kedua dalam penelitian ini menunjukkan bahwa perusahaan yang dimiliki oleh institusional yang tinggi tidak serta merta meningkatkan nilai perusahaan. Artinya kepemilikan oleh institusional atas perusahaan tidak akan selalu menyebabkan kenaikan pada nilai perusahaan tersebut. 
(online)

Vol 4, No 2, Desember 2019

http://journal.undiknas.ac.id/index.php/manajemen

\section{SIMPULAN}

Kepemilikan keluarga yang diproksikan dengan FM dummy berpengaruh negatif dan signifikan terhadap nilai perusahaan sedangkan FO dummy dan family ownership percentage mempunyai pengaruh negatif dan tidak signifikan. Hal ini berarti perusahaan yang anggota keluarga menjabat dalam jajaran direksi dan komisaris memiliki rata-rata nilai perusahaan yang lebih rendah dibandingkan dengan rata-rata nilai perusahaan yang tidak terdapat anggota keluarga. Kepemilikan institusional yang diproksikan dengan institutional ownership mempunyai pengaruh negatif dan tidak signifikan terhadap nilai perusahaan, yang artinya nilai perusahaan tidak dipengaruhi dari persentase kepemilikan oleh institusi pada perusahaan tersebut.

Berdasarkan hasil penelitian yang telah dikemukakan maka dapat diberikan beberapa saran bagi perusahaan, penelitian ini dapat digunakan sebagai pertimbangan dalam penentuan direksi dan komisaris perusahaan agar berdasarkan kemampuan dan keahliannya atau yang profesional dibidangnya. Dari sisi investor, penelitian ini dapat dijadikan masukan saat akan melakukan investasi dengan memperhatikan kemampuan dan eahlian dewan direksi dan komisaris pada perusahaan keluarga.

Penelitian ini memiliki beberapa keterbatasan. Pertama, penelitian ini hanya meneliti tentang nilai perusahaan di satu sektor saja pada Bursa Efek Indonesia. Hal ini membuat penelitian berada pada ruang lingkup yang kecil. Kedua, penelitian hanya meneliti sebagian kecil dari faktor corporate governance yang mempengaruhi nilai perusahaan.

\section{REFERENSI}

Abdullah, F., Shah, A., Gohar, R., \& Iqbal, A. M. (2011). The Effect of Group and Family Ownership on Firm Performance: Empirical Evidence from Pakistan. International Review of Business Research Papers, 7(4), 191208.

Adnantara, K. F. (2014). Pengaruh struktur kepemilikan saham dan corporate social responsibility pada nilai perusahaan. Buletin studi ekonomi; vol.18.no.2.agustus 2013. (pp 85-190).

Altindag, E., Zehir, C., \& Acar, A. Z. (2011). Strategic Orientations and Their Effects on Firm Performance in Turkish Family Owned Firms. Eurasian Business Review, 1(1), 18-36. doi:10.14208/BF03353796

Amran, N. A., \& Ahmad, A. C. (2010). Family Succession and Firm Performance Among Malaysian Companies. International Journal of Business and Social Science, 1(2), 193-203.

Andres, C. (2011). Family ownership, financing constraints and investment decisions. Applied Financial Economics, 21(22), 1641-1659. doi:10.1080/09603107.2011.589805

Barontini, R., \& Caprio, L. (2006). The Effect of Family Control on Firm Value and Performance: Evidence from Continental Europe. European Financial Management, 12(5), 689-723. doi:10.1111/j.1468-036X.2006.00273.x

Benson, B. W., \& Davidson, W. N. (2009). Reexamining the managerial ownership effect on firm value. Journal of Corporate Finance, 15(5), 573-586. doi:https://doi.org/10.1016/j.jcorpfin.2009.08.002 
(online)

Vol 4, No 2, Desember 2019

http://journal.undiknas.ac.id/index.php/manajemen

Chu, W. (2011). Family Ownership and Firm Performance: Influence of Family Management, Family Control and Firm Size. Asia Pacific Journal of Management, 28(4), 833-851.

Connelly, J. T., Limpaphayom, P., \& Nagarajan, N. J. (2012). Form versus substance: The effect of ownership structure and corporate governance on firm value in Thailand. Journal of Banking \& Finance, 36(6), 1722-1743. doi:https://doi.org/10.1016/j.jbankfin.2012.01.017

FCGI. (2001). Peranan Dewan Komisaris dan Komite Audit dalam pelaksanaan Corporate Governance. Jakarta.

Harahap, L. H., \& Wardhani, R. (2012). Analisis Komprehensif Pengaruh Family Ownership, Masalah Keagenan, Kebijakan Dividen, Kebijakan Hutang, Corporate Governance dan Opportunity Growth terhadap Nilai Perusahaan. . Paper presented at the Simposium Nasional Akuntansi, Banjarmasin.

Haruman, T. (2008). Pengaruh Struktur Kepemilikan Terhadap Keputusan Keuangan dan Nilai Perusahaan. Paper presented at the Simposium Nasional Akuntansi Makassar.

Hitt, M. A., Ireland, R. D., \& Hoskisson, R. E. (2011). Strategic management: competitiveness and globalization (Vol. 9th, International student). Mason, Ohio: South-Western.

International Finance Corporation. (2014). The Indonesia Corporate Governance Manual.

Isshaq, Z. (2009). Corporate governance, ownership structure, cash holdings, and firm value on the Ghana Stock Exchange. The Journal of Risk Finance, 10(5), 488-499. doi:10.1108/15265940911001394

Jensen, M. C., \& Meckling, W. H. (1976). Theory of the firm: Managerial behavior, agency costs and ownership structure. Journal of Financial Economics, 3(4), 305-360. doi:https://doi.org/10.1016/0304-405X(76)90026-X

Komalasari, P. T., \& Nor, M. A. (2014). Pengaruh Struktur Kepemilikan Keluarga, Kepemimpinan dan Perwakilan Keluarga terhadap Kinerja Perusahaan Akrual: Jurnal akuntansi, 5(2), 133-150.

Lee, J. (2006). Family Firm Performance: Further Evidence. Family Business Review, 19(2), 103-114. doi:10.1111/j.1741-6248.2006.00060.x

Lin, Y. R., \& Fu, X. M. (2017). Does institutional ownership influence firm performance? Evidence from China. International Review of Economics \& Finance, 49, 17-57. doi:https://doi.org/10.1016/j.iref.2017.01.021

Liviani, S., Mahadwartha, P. A., \& Wijaya, L. I. (2016). Uji Model Keseimbangan Teori Keagenan: Pengaruh Kebijakan Utang dan Kebijakan Dividen terhadap Kepemilikan Manajerial. Development Research of Manajemen: Jurnal Manajemen, 11(1), 102-120.

Martínez, B., \& Requejo, I. (2017). Does the Type of Family Control Affect the Relationship Between Ownership Structure and Firm Value? International Review of Finance, 17(1), 135-146. doi:10.1111/irfi.12093

Melinda, F. I., \& Sutedo, B. S. (2008). Interpendensi Kepemilikan Manajerial dan Kepemilikan Institusional serta Pengaruhnya terhadap Kinerja Keuangan. Journal of Management and Business, 7(2), 167-182.

Miller, D., Le Breton-Miller, I., Lester, R. H., \& Cannella, A. A. (2007). Are family firms really superior performers? Journal of Corporate Finance, 13(5), 829858. doi:https://doi.org/10.1016/j.jcorpfin.2007.03.004 
(online)

Vol 4, No 2, Desember 2019

http://journal.undiknas.ac.id/index.php/manajemen

Nam, J., Tang, C., Thornton, J. H., \& Wynne, K. (2006). The effect of agency costs on the value of single-segment and multi-segment firms. Journal of Corporate Finance, 12(4), 761-782. doi:10.1016/j.jcorpfin.2005.06.003

Pillai, R., \& Al-Malkawi, H.-A. N. (2018). On the relationship between corporate governance and firm performance: Evidence from GCC countries. Research in International Business and Finance, 44, 394-410. doi:https://doi.org/10.1016/j.ribaf.2017.07.110

Pujiati, D., \& Widanar, E. (2009). Pengaruh Struktur Kepemilikan terhadap Nilai Perusahaan: Keputusan Keuangan sebagai variabel Intervening. Jurnal Ekonomi Bisnis \& Akuntansi Ventura, 12(1), 71-86.

Pukthuanthong, K. (2013). Does family ownership create or destroy value? Evidence from Canada. International Journal of Managerial Finance, 9(1), 13-48. doi:10.1108/17439131311298511

PWC. (2014). Survey Bisnis Keluarga 2014 Indonesia. Retrieved from

Rouyer, E. (2016). Family ownership and busy boards: impact on performance. Management Decision, 54(4), 832-853. doi:10.1108/MD-04-2015-0144

Sari, R. M., \& Patrisia, D. (2019). The Effect of Institutional Ownership, Capital Structure, Devidend Policy and Company's Gwroth on Firm Value. Paper presented at the Third PICEEBA, Padang.

Shyu, J. (2011). Family ownership and firm performance: evidence from Taiwanese firms. International Journal of Managerial Finance, 7(4), 397411. doi:10.1108/17439131111166393

Villalonga, B., \& Amit, R. (2006). How do family ownership, control and management affect firm value? Journal of Financial Economics, 80(2), 385417. doi:https://doi.org/10.1016/i.jfineco.2004.12.005

Widianingsih, D. (2018). Kepemilikan Manajerial, Kepemilikan Institusional, Komisaris Independen, serta Komite Audit pada Nilai Perusahaan dengan Pengungkapan CSR sebagai Variabel Moderating dan Firm Size sebagai Variabel Kontrol. Jurnal Akuntansi dan Pajak, 19(1), 38-52. doi:http://dx.doi.org/10.29040/iap.v19i1.196. 